\title{
ВИКОРИСТАННЯ МЕТЕОРОЛОГІЧНИХ ТА ГЕОМОРФОЛОГІЧНИХ ДАНИХ ПРИ РОЗРАХУНКУ ПАВОДКОВИХ СТОКІВ
}

\begin{abstract}
Виконано аналіз катастрофічних паводків у басейні Дністра в Карпатах, найбільшим з яких є червневий паводок 1969 р., коли було досягнуто сторічного максимального стоку. Проаналізовано сучасні методи розрахунку паводкових стоків. Запропоновано метод розрахунку, заснований на генетичній формулі стоку та цифровій моделі рельєфу. Розроблено цифрові моделі рельєфу верхніх частин басейнів річок Свіча та Бистриця Солотвинська, карти ізохрон стоку. Виконано розрахунок максимального стоку на основі генетичної формули. Виконані дослідження показують, що обмеженість та низька точність вихідних метеорологічних та геоморфологічних даних не гарантують точних розрахунків та захисту від небезпечних паводків навіть 3 використанням найсучасніших геоінформаційних систем. Тому важливими $є$ аналіз і використання результатів багаторічних спостережень за паводками у попередні роки. Вони дають змогу певною мірою прогнозувати наслідки дощових паводків. Подальший прогрес у гідрологічних розрахунках пов'язаний з детальними знаннями про рельєф, які дає цифрова модель рельєфу. На основі цифрової моделі рельєфу створено просторово-часову модель паводкового стоку, в якій для кожної вершини регулярної сітки визначено координати, ухили поверхні, віддалі до водорозділу та до водного потоку, інтенсивність і шар опадів. Використання цифрової моделі рельєфу дасть змогу розробити для кожного басейну регіональну методику розрахунку паводків, врахувати максимум параметрів поверхневого стоку, а також зміну їх у часі.
\end{abstract}

Ключові слова: інтенсивність опадів; цифрова модель рельєфу; гідрограф; ізохрони; басейн річки.

Вступ. Сильні зливи в Карпатах формують на річках басейну Дністра дощові паводки, часто катастрофічного характеру. Вони завдають значної шкоди населеним пунктам, промисловим об'єктам, лініям транспорту та зв'язку. Боротьба з наслідками паводків $є$ дуже актуальною проблемою для Карпат і басейну Дністра зокрема. Для захисту від паводків складають проекти спорудження комплексу водосховищ, дамб для регулювання паводкового стоку.

Існує багато досліджень, де розглянуто питання формування, розрахунку та прогнозування паводкових стоків, визначено параметри максимальних витрат і шарів дощових стоків різної забезпеченості. Важливим $\epsilon$ питання прогнозування дощових паводків. Сучасні методи та засоби реєстрації та передачі гідрометеоданих не можуть забезпечити необхідну точність прогнозування паводків.

Останнім часом розроблено багато моделей формування стоку з річкових басейнів для прогнозування паводків, розроблення заходів для запобігання їх негативним наслідкам. Серед них методи, засновані на розв'язанні диференціальних рівнянь, стохастичні моделі (Befani, 1977; Bojko, 2015; Grushevskij, 1969; Kuchment, 1972; Kussul, 2008; Kravets, 2005; Trofymchuk, 2012).

Метою цього дослідження $\epsilon$ вдосконалення методу розрахунку паводкових стоків.
Матеріали та методика дослідження. Зливи в басейні Дністра відбуваються щорічно, а деколи по кілька разів на рік. Найінтенсивніші з них призводять до значних паводків. Особливо катастрофічними були паводки у червні 1969 р., у травні 1970 р. та в липні 2008 р. Дощі можуть тривати кілька днів, а зливи - до 10 год. Під час повені 8 червня 1969 р. у басейні Бистриці Солотвинської в районі села Гута інтенсивність дощу 1020 мм/год тривала 9 год за загальної тривалості дощу 65 год. Злива 7-11 червня 1969 р. охопила одночасно велику територію Карпатського регіону. Графік формування червневого паводка 1969 р. наведено на рис. 1. Величина сумарного шару опадів у районі села Гута становила 320 мм, що відповідає максимальному значенню за 100 років. Аналогічна ситуація спостерігалась і в басейні річки Свіча.

За останні роки виконано низку досліджень із прогнозування паводків у басейні Дністра. Вони грунтуються на гідрометеорологічних і геоморфологічних фактоpax. Усі методи гідрологічних розрахунків умовно поділяють на строгі і спрощені. Строгі методи грунтуються на розв'язанні системи рівнянь Сен-Венана, які записують у такому вигляді (Kuchment, 1972):

$$
\frac{\partial u}{\partial t}+u \frac{\partial u}{\partial x}+g \frac{\partial h}{\partial x}+\frac{\left(u-u_{q}\right) \cdot q}{F}=q \cdot\left(i_{0}-i_{s}\right), \frac{\partial Q}{\partial x}+\frac{\partial F}{\partial t}=q,
$$

де: $x$ - відстань від початкового створу; $t$ - час; $g$ пришвидшення сили тяжіння; $Q, u, h, F$ - витрати води,

\section{Інформація про авторів:}

Кравець Олена Ярославівна, канд. техн. наук, доцент, доцент кафедри землевпорядкування та кадастру. Email: olenakravets9@gmail.com

Цитування за Дсту: Кравець О. Я. Використання метеорологічних та геоморфологічних даних при розрахунку паводкових стоків. Науковий вісник НлтУ України. 2018, т. 28, № 2. С. 129-132.

Citation APA: Kravets, O. Ya. (2018). The Use of Meteorological and Geomorphological Data in the Calculation of Rain Floods. Scientific Bulletin of UNFU, 28(2), 129-132. https://doi.org/10.15421/40280224 
швидкість, глибина та площа живого перерізу потоку; $q$ - боковий приток; $u_{q}$ - швидкість бокового притоку; $i_{0}-$ ухил поверхні води; $i_{s}-$ ухил тертя.

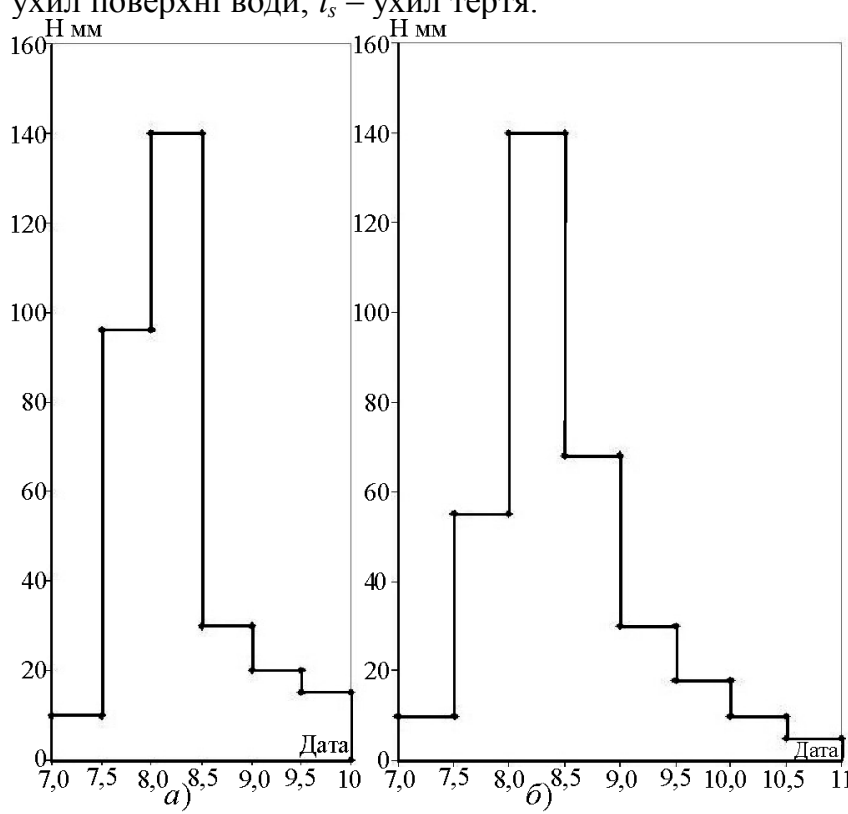

Рис. 1. Інтенсивність опадів у Нмм/год під час формування червневого паводка 1969 р. у басейнах річок Бистриця Солотвинська (а) та Свіча (б)

Але, незважаючи на складний математичний апарат, який використовують для розв'язанні рівнянь Сен-Венана, за відсутності достатньої інформації про рельєф кінцеві результати цих розв'язків будуть наближеними.

Відомий також генетичний метод розрахунку паводкового стоку, який запропонував М. А. Веліканов. Цей метод полягає в послідовному сумуванні елементарних об'ємів стоку, які сформувались у різних частинах басейну та які одночасно проходять через розрахунковий створ. Поточні витрати паводка можна визначити за так званою генетичною формулою стоку:

$$
Q=\int_{0}^{t} \frac{\partial f}{\partial t} h d t
$$

де: $Q$ - поточна витрата паводка; $f$ - площа одночасного стікання; $h$ - шар стоку.

Результати дослідження. Для побудови гідрографа паводкового стоку генетичним способом потрібно мати дані про опади, про швидкості стікання по схилах і русловій мережі та великомасштабний план басейну, за якими будують лінії одночасного добігання води до розрахункового створу. Ці лінії називають ізохронами.

Якщо прийняти постійними швидкості стікання води, то витрати паводка визначають за такою формулою:

$$
Q_{i}=h_{i} \cdot f_{1}+h_{i-1} \cdot f_{2}+\ldots+h_{1} \cdot f_{i}=\sum_{k=1}^{k=i} h_{k} \cdot f_{i-k+1},
$$

де: $h_{i}$ - шари водовіддачі; $f_{i}$ - площі одночасного стікання, обмежені сусідніми ізохронами.

Цей метод досить точно відображає процес формування паводків і використовується у розрахунках максимальних витрат. Недоліком методу є складність проведення ізохрон при складному рельєфі. Складним і неточним є облік опадів і втрат води на фільтрацію. До недоліків відносять допущення постійності руслових швидкостей, хоч багато дослідників вважають, що це дійсно існує в широкому діапазоні рівнів води.

Для реалізації генетичного методу ізохрон розроблено цифрові моделі рельєфу для частин басейнів річок
Бистриця Солотвинська (до поста Гута) і Свіча (до поста Мислівка). На рис. 2 наведено ЦМР басейну річки Свіча.

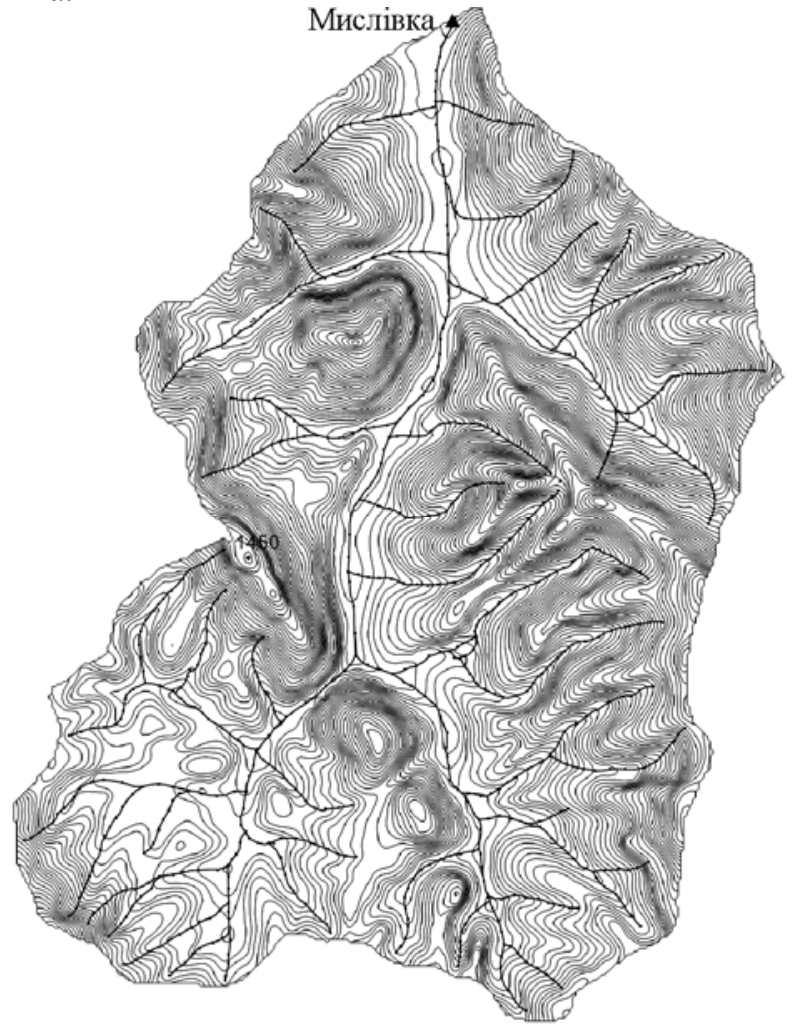

Рис. 2. Цифрова модель рельєфу басейну річки Свіча

Для кожного басейну було визначено за ЦМР такі морфометричні характеристики, як площа, довжина, середня ширина, середній ухил, довжина та щільність гідрографічної мережі.

Для кожної точки ЦМР визначено віддалі $l$ до річкової мережі та віддалі $L$ руслового добігання до водомірного поста. Час добігання води $T$ по басейну складається зі схилового та руслового добігання:

$$
T=t_{c x}+t_{p}=\frac{l_{\min }}{v_{c x}}+\frac{L_{P}}{v_{P}},
$$

де: $v_{c x}$ - швидкість схилового стікання; $v_{p}$ - швидкість руслового стікання.

Об'єм стоку за інтервал часу $\Delta t$ визначають за такою формулою:

$$
W=n \cdot f \cdot h \cdot \Delta t,
$$

де: $n$ - число $T$, які потрапили в інтервал $\Delta t ; f$ - площа квадрата регулярної сітки моделі; $h$ - шар водовіддачі.

Швидкість стікання води залежить від висоти шару водовіддачі, ухилу поверхні та визначається за гідрологічними формулами Шезі, Шезі-Манінга та інших автоpiв (Ljutik, 1971). За даними багаторічних спостережень (Sosedko, 1973), руслова швидкість під час катастрофічних паводків змінюється від 2 до 6 м/с.

За розробленим методом побудовано карти ізохрон (рис. 3) та розраховано гідрографи максимальних стоків. На рис. 4 наведено гідрограф максимального стоку червневого паводка для басейну річки Бистриця Солотвинська для поста Гута.

Основними причинами паводків є метеорологічні фактори, а саме інтенсивність, тривалість та поширеність опадів. Прогнозувати ці фактори дуже складно за недостатньої спостережної гідрометеорологічної мережі, а також кліматичних катаклізмів, які стаються в ос- 
танній період. Обмеженість та низька точність вихідних метеорологічних і геоморфологічних даних не гарантують точних розрахунків та захисту від небезпечних паводків навіть у разі використання найсучасніших геоінформаційних систем. Тому важливими $\epsilon$ аналіз і використання результатів багаторічних спостережень за паводками в попередні роки. Вони дають змогу певною мірою прогнозувати наслідки дощових паводків.

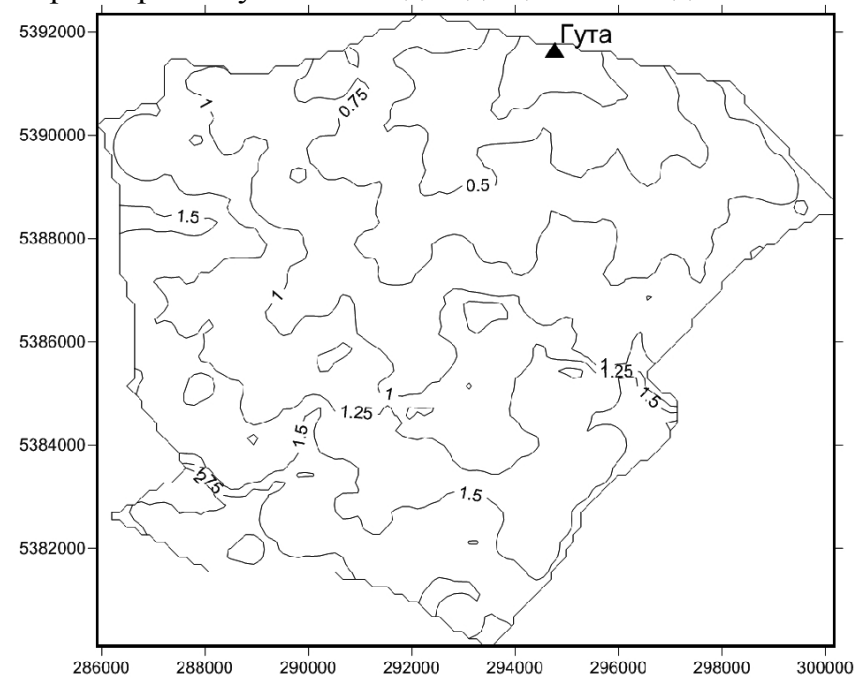

Рис. 3. Карта ізохрон для басейну річки Бистриця Солотвинська для поста Гута (ізохрони проведені через 0,25 год)

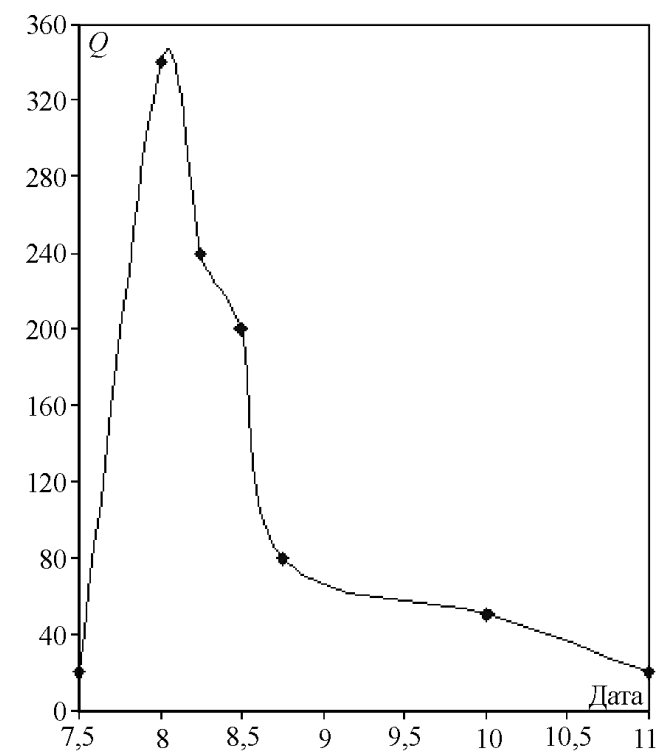

Рис. 4. Гідрограф максимального стоку для басейну річки Бистриця Солотвинська для поста Гута

Так, порівнюючи графіки опадів і гідрограф максимальних стоків паводка 8 червня 1969 р., можна зроби- ти висновок про те, що збільшення максимальних витрат прямо пропорційно залежить від збільшення водоутворення.

Висновки. Виконано аналіз сучасних методів розрахунку та прогнозу паводкових стоків. Запропоновано метод розрахунку та прогнозу паводкового стоку на основі цифрової моделі рельєфу та генетичної формули стоку. Виконано моделювання червневого паводка 1969 р., який був найбільшим за весь період спостережень. Розроблено цифрові моделі рельєфу верхніх частин басейнів річок Свіча та Бистриця Солотвинська, графіки інтенсивності опадів і гідрограф паводкового стоку. Запропоновано метод створення просторово-часової гідрологічної моделі паводкового стоку на основі ЦМР.

\section{Перелік використаних джерел}

Befani, N. F. (1977). Prognozirovanie dozhdevyh pavodkov na osnove territorial'no obshhih zavisimostej [Forecasting rainfalls based on geographically common dependencies]. Leningrad: Gidrometeoizdat. [in Russian].

Bojko, A. V., \& Zheleznjak, M. J. (2015). Tehnologija parallel'noj obrabotki prostranstvenno raspredelennoj informacii $\mathrm{v}$ modeli stoka rechnogo vodosbora [The technology of parallel processing of spatially distributed information in the river basin drainage model]. Jelektronnoe modelirovanie, 1, 97-111. [in Russian].

Grushevskij, M. S. (1969). Volny popuskov i pavodkov v rekah [Waves of releases and floods in rivers]. Leningrad: Gidrometeoizdat. [in Russian].

Kravets, O. Ya. (2005). Alhorytm prohnozuvannia pavodochnoho sto$\mathrm{ku}$ [The flood forecasting algorithm]. Ekolohiia dovkillia ta bezpeka zhyttiediialnosti, 1, 33-36. [in Ukrainian].

Kuchment, L. S. (1972). Matematicheskoe modelirovanie rechnogo stoka [Mathematical modeling of river flow]. Leningrad: Gidrometeoizdat. [in Russian].

Kussul, N., Shelestov, A., \& Kravchenko, O. (2008). Data assimilation technique for flood monitoring and prediction. Information Theories \& Applications, 15, 76-83.

Ljutik, P. M. (1971). Livnevye pavodki na rekah Karpat v ijune 1969, mae $1970 \mathrm{~g}$ [Storm floods on the rivers of the Carpathians in June 1969, May 1970]. Trudy UkrNIGMI, 100, 75-85. [in Russian].

Sosedko, M. N. (1973). Zavisimost' harakteristik maksimal'nyh rashodov vody dozhdevyh pavodkov rek bassejna Dnestra [Dependence of the characteristics of the maximum flow of water from river floods in the Dniester Basin]. Trudy UkrNIGMI, 123, 99-118. [in Russian].

Trofymchuk, O. M., \& Trysniuk, V. M. (2012). Potentsial heoinformatsiinykh tekhnolohii u vyrishenni problem ekolohichnoi bezpeky vodnykh ob'iektiv [Potential of geoinformation technologies in solving environmental safety problems of water objects]. Ekolohichna bezpeka ta pryrodokorystuvannia, 11, 19-29. [in Ukrainian].

Е. Я. Кравец

Ивано-Франковский национальный технический университет нефти и газа, г. Ивано-Франковск, Украина

\section{ИСПОЛЬЗОВАНИЕ МЕТЕОРОЛОГИЧЕСКИХ И ГЕОМОРФОЛОГИЧЕСКИХ ДАННЫХ ПРИ РАСЧЕТЕ ПАВОДОЧНЫХ СТОКОВ}

Выполнен анализ катастрофических паводков в бассейне Днестра в Карпатах, самым большим из которых является июньский паводок 1969 г., когда был достигнут столетний максимум стока. Проанализированы существующие методы расчета паводочных стоков. Предложен метод расчета, основанный на генетической формуле стока и цифровой модели рельефа. Разработаны цифровые модели рельефа верхних частей бассейнов рек Свеча и Быстрица Солотвинская, карты изохрон стока. Выполнен расчет максимального стока на основе генетической формулы. Выполненные исследования показывают, что ограниченность и низкая точность исходных метеорологических и геоморфологических данных не гарантируют точных расчетов и защиты от опасных паводков даже при использовании самых современных геоинформационных систем. Поэтому важны анализ и использование результатов многолетних наблюдений за паводками в предыдущие годы. Они позволяют в некоторой степени прогнозировать последствия дождевых паводков. Дальнейший прогресс в гидрологических расчетах 
связан с детальными знаниями о рельефе, которые дает цифровая модель рельефа. На основе цифровой модели рельефа создана пространственно-временная модель паводочного стока, в которой для каждой вершины регулярной сетки определены координаты, уклоны поверхности, расстояния до водораздела и до водного потока, интенсивность и шар осадков. Использование цифровой модели рельефа позволяет разработать для каждого бассейна региональную методику расчета паводков, учитывать максимум параметров поверхностного стока, а также их изменение во времени.

Ключевые слова: интенсивность осадков; цифровая модель рельефа; гидрограф; изохроны; бассейн реки.

O. Ya. Kravets

Ivano-Frankivsk National Technical University of Oil and Gas, Ivano-Frankivsk, Ukraine

THE USE OF METEOROLOGICAL AND GEOMORPHOLOGICAL DATA IN THE CALCULATION OF RAIN FLOODS

Heavy rains in the Carpathians form rain floods, often of a catastrophic character, on the rivers of the Dniester basin. Therefore, the fight against the effects of floods is a very urgent problem. The improving of the method of calculating of flood flows based on the genetic formula is the purpose of these researches. It is necessary to have data on precipitation, velocity of flowing down on slopes and river network, and large-scale plan of the basin to construct lines of simultaneous running of water to the settlement point, for construction of a flood discharge hydrograph by the genetic method. These lines are named isochronous. This method accurately represents the process of forming of floods and it is used in calculations of maximal charges. The disadvantage of the method is the inaccuracy of conducting of isochronous at the complex relief. The use of DEM simplifies the conducting of isochronous. Digital models of relief were developed for parts of the basins of the Bystrytsa Solotvinska and the Svicha rivers for the implementation of the isochronous method. The following morphometric characteristics such as area, length, average width, mean slope, length and density of the hydrographical network, were determined by DEM for each basin. Distances to the river network and distances of channel reach to the water meter post are determined for each DEM point. The accuracy of this method depends on the accuracy of determining the water efficiency and the accuracy of determining the rate of drainage of water, which depends on the amount of precipitation. Maps of the isochronous are constructed and hydrographs of maximum runoff are calculated according to the developed method. The limitation and low accuracy of output meteorological and geomorphological data do not guarantee accurate calculations and protection against dangerous floods, even with the use of most up-to-date GIS. Therefore, it is important to analyse and use the results of long-term flood observations in previous years. They allow to some extent predicting the effects of rain floods. The performed researches allow increasing the objectivity and accuracy of calculations and create a spatial-temporal hydrological model of flood runoff.

Keywords: intensity of precipitation; digital terrain model; hydrograph; isochronous; river basin. 